\title{
A FRAMEWORK FOR DISPUTE RESOLUTION- THE INDUSTRY OMBUDSMEN IN NEW ZEALAND
}

\section{Liz Brown"}

New Zealand is a small and sparsely populated country with a penchant for bursts of radical legislation that have earned it a reputation as a social laboratory. One consequence of its size is the comparatively simple structure of its constitutional arrangements, which until recently have included a small legislature comprised of a single chamber tightly controlled by the government of the day. ${ }^{\prime}$ This permits legislation to be introduced and passed with a speed that has variously been described as exhilarating and terrifying.

In this context, it is not surprising that the first Ombudsman outside Scandinavia was appointed in New Zealand (in 1962) nor that the institution of the Ombudsman became one of some constitutional significance particularly after the Official Information Act 1982 gave the Ombudsmen responsibility for determining disputes over access to information held by government departments and agencies. ${ }^{2}$ The concept of the Ombudsman as an independent authority of considerable stature took root in the New Zealand popular consciousness and is reflected both in the Maori title for the office - Te Kaitiaki Mana Tangata ${ }^{3}$ - and in the statutory protection for the name "Ombudsman", which cannot be used without the consent of the Chief Ombudsman. ${ }^{4}$ The institution became seen as one of a limited array of checks on the executive power of government.

* New Zealand Banking Ombudsman

1 A proportional representation system was introduced in 1996. It is too early to evaluate its effects, but it seems likely that the norm will become minority or coalition governments with less scope for rapid and radical legislative change.

${ }^{2}$ The Privacy Act 1993 now governs access to personal information held by government and other agencies.

3 "The guardian of the mana of the people." "Mana" is a word that is almost untranslatable, but carries connotations of power, status and both temporal and spiritual authority.

4 Ombudsmen Act 1975 s. 28 A. 
The original objective of the Ombudsman legislation was to provide a remedy where there was no recourse to the courts. ${ }^{5}$ Section $13(7)(a)$ of the Ombudsmen Act prohibits the Ombudsmen from investigating:

"Any decision, recommendation, act, or omission in respect of which there is, under the provisions of any Act or regulation, a right of appeal or objection, or a right to apply for a review, available to the complainant, on the merits of the case, to any Court, or to any tribunal constituted by or under any enactment, whether or not that right of appeal or objection or application has been exercised in the particular case, and whether or not any time prescribed for the exercise of that right has expired.

Provided that the Oinbudsman may conduct an investigation (not being an investigation relating to any decision, recommendation, act, or omission to which any other paragraph of this subsection applies) notwithstanding that the complainant has or had such right if by reason of special circumstances it would be unreasonable to expect him to resort or have resorted to it."

The discretion conferred by the proviso to section 13(7)(a) is often exercised when the only alternative open to a complainant is to apply for judicial review, but rarely in other circumstances. In general, the Ombudsmen are not seen, and do not see themselves as an altemative to litigation. Possibly as a result of this attitude, the courts have taken a respectful view of their relationship with the Ombudsmen on the occasions when Ombudsmen decisions are before them.

"Parliament delegated to the Chief Ombudsman tasks, which at times are complex and even agonising, with no expectation that the Courts would sit on his shoulder about those judgements which are essentially balancing exercises involving competing interests. The courts will only intervene when the Chief Ombudsman is plainly and demonstrably wrong."

Private sector ombudsmen were late arriving in New Zealand: the Banking Ombudsman scheme commenced in 1992 and the Insurance and Savings

${ }^{5}$ The original legislation was the Parliamentary Commissioner (Ombudsman) Act 1962.

${ }^{6}$ Jeffries, J. in Wyatt Co (NZ) Ltd v Queenstown-Lakes District Council [1991] 2 N.Z.L.R. 180 . 
Ombudsman scheme in 1994. With a thirty year history behind it the classical Ombudsman role is so well known that it is sometimes difficult, even for lawyers, to accept that the private sector schemes may use much the same process of investigation but have quite a different role. In particular they have no statutory base, and their main function is to offer a low-cost, speedy and specialised alternative to litigation for all but the most complex or high value claims against scheme members.?

Where the classical Ombudsmen have generally acted as a supplement to the law in the sense that they offer a remedy where litigation does not, the private sector Ombudsmen are a genuine alternative to litigation and in many ways are more closely linked with legal practice outside the specialised area of administrative law. In making determinations of complaints they apply the law, they use formal supplements to the law in the form of codes of practice, they use informal supplements in seeking to establish good practice in areas where codes are silent and they work in parallel with the law when their investigations impinge on legal action taken by the organisations subject to their jurisdiction, often in the field of debt recovery.

In the case of the Banking Ombudsman, the Terms of Reference are specific about the Ombudsman's obligations in making determinations. Paragraph 16 provides:

"In making any recommendation or award under these Terms of Reference the Banking Ombudsman shall do so by reference to what is, in his or her opinion, fair in all the circumstances, and

(a) shall observe any applicable rule of law or relevant judicial authority (including but not limited to any such rule or authority concerning the legal effect of the express or implied terms of any contract between the complainant and any Participating Bank names in the complaint); and

(b) shall have regard to general principles of good banking practice and any relevant code of practice applicable to the subject matter of the complaint.

The Banking Ombudsman shall not be bound by any previous decision made by him or her or by any predecessor in his or her office. In determining what are the principles of good banking practice he or she shall consult within the industry."

${ }^{7}$ The jurisdictional limit is currently $\$ 100,000$ for both schemes. 
There is similar provision in the Terms of Reference for the Insurance and Savings Ombudsman, with one major difference. Paragraph 5.6 of those Terms of Reference reads:
"In making any recommendation or award under these Terms of Reference the Insurance and Savings Ombudsman shall do so by reference to what is, in his or her opinion, fair in all the circumstances, and in so doing, except to the extent that he or she considers in all the circumstances that it would be inappropriate to do so, shall have regard to...(a) any applicable rule of law...."

The remainder of the paragraph is almost identical to Paragraph 16, except that there is some detail as to the matters that the Insurance and Savings Ombudsman may consider in determining what is fair and reasonable.

\section{APPLYING THE LAW}

The first and obvious way in which Ombudsmen interact with the legal system in general is by applying the law in making determinations. Even here, however, there is room for different approaches as can be seen from the different provisions of the Terms of Reference cited above. While only some of our more optimistic complainants would suggest that an Ombudsman should ignore basic legal principles, such as those that govern the formation of contracts, a more difficult question can arise when an Ombudsman is operating in an area of law where it is generally acknowledged that the existing judicial authority is unsatisfactory or confusing.

In such a case the Insurance and Savings Ombudsman has some basis for reaching a conclusion that is not strictly in accordance with existing precedent, and indeed has done so in some cases where insurance companies sought to decline claims by reason of non-disclosure of material information by the insured person. The law on non-disclosure is in need of clarification and is generally thought to place too onerous an obligation on applicants in respect of the need to disclose information. ${ }^{9}$ Relying in part on the Fair Insurance Code ${ }^{10}$ and in part on the "fair in all the

8 Emphasis added.

${ }^{9}$ See, for example, Report no. 46 of the Law Commission, "Some Insurance Law Reforms".

${ }^{10}$ Infra. 
circumstances" jurisdiction, the Insurance and Savings Ombudsman has taken the view that although an insured person generally has a duty to disclose material facts whether or not the insurer has asked for the relevant information:

\begin{abstract}
"in some cases I may find that where an insurer has not asked any questions, has not asked enough questions or has not asked sufficiently clear questions, that they have behaved unfairly towards the complainant. In such circumstances .... I may find in favour of the complainant."
\end{abstract}

It is not certain whether the Banking Ombudsman would be able to take the same approach, at least where the legal precedents are reasonably clear. The handling of insurance claims is a contentious business and there is a good deal of case law directly on points likely to come before an Ombudsman operating in that field. Comparatively few of the complaints that come before a Banking Ombudsman involve issues where case law is likely to have some direct application. I incline to the view that the requirement to "observe" rules of law and judicial authority gives a little latitude for divergence, but have not yet been faced with the need to test this view.

It is much more clear that a bank will not necessarily be absolved of all responsibility to a complainant by fulfilling its legal obligations. In several cases I have found that although a bank was entitled at law to demand payment from a complainant and had complied with the procedural requirements in making demand, it was unreasonable and unfair, given the circumstances of the case, to expect the complainant to comply.

In a case reported in a recent annual report, for example, an elderly couple had been persuaded to purchase an investment property jointly with a young businessman. The purchase was to be financed by way of a capital sum provided by the couple and a loan in the names of all three participants, secured against the property and serviced by the young man. The loan repayments fell into arrears at an early stage and after some months the young man disappeared overseas, leaving substantial debts behind. The couple sought the transfer of the property title into their names only, by way of part repayment of debts owed to them by the other party. At this point they discovered that at a date after the loan offer had been made but before the loan documents had been executed, the bank had granted him a personal overdraft of some $\$ 3,000$ (since increased by the accrual of interest). The

\footnotetext{
${ }^{11}$ Report of the Insurance and Savings Ombudsman for the year ended 30 June 1996, p. 15.
} 
bank required repayment of the overdraft as well as the loan before it would consent to the transfer of title.

Investigation revealed that the loan document was an "all obligations" mortgage and that on its execution the overdraft became secured against the property. It also became clear that the overdraft had been granted on an unsecured and informal basis (in fact it was not documented at all) and that there was no way in which the complainants could have known about it when they entered into the loan agreement. While it could not be said that the bank had a positive duty to disclose the existence of the overdraft when the loan documents were executed, it was in all the circumstances unfair for it to expect repayment from the complainants. ${ }^{12}$

\section{FORMAL SUPPLEMENTS TO THE LAW - CODES OF PRACTICE}

Industry codes of practice are perhaps best seen as a means of fleshing out the framework of the law as it applies to the individual industry. A bank that has failed to comply with the requirements of the Code of Banking Practice is likely to be in breach of its contract with a customer if the Code is incorporated into the terms and conditions on which it supplies services. Non-compliance may be evidence of negligence, and it may also be a breach of a statutory duty. In a recent case where the plaintiff claimed a breach of the Fair Trading Act 1986, Justice Doogue remarked:

"[The Code of Banking Practice] is a clear guide to good banking practice. A breach of it must always be likely to give rise to misleading conduct." ${ }^{.13}$

The Code of Banking Practice effectively acts in three ways as a guide for assessing banks' conduct. It contains information about the law applying to the banker/customer relationship; it sets some specific rules which banks are obliged to incorporate into their contractual arrangements with their personal customers and it contains some more general statements of the principles which banks are expected 58.

${ }^{12}$ Case reported in full as 'Case 9k', Armual Report of the Banking Ombudsman 1997/8, p.

${ }^{13}$ Dungey v ANZ Banking Group (NZ) Ltd [1997] N.Z.F.L.R. 404 


\section{A FRAMEWORK FOR DISPUTE RESOLUTION}

to observe. ${ }^{14}$

Information about the law, such as the information contained in clause 7.2 about the circumstances in which banks may refuse payment on bank cheques, is no doubt of assistance to customers in understanding the nature of banking transactions they may have undertaken, but is not often relevant to complaint investigation. If an investigation involves a point of law, it is usually necessary to go back to the statutory or other authority to establish the legal basis for the determination of the complaint.

Parts of the Code of Banking Practice are quite specific as to the obligations undertaken by a bank that subscribes to it. It contains, for example, the basic rules about liability for loss caused by the use of bank cards for unauthorised transactions. Banks may issue cards on terms that are more favourable to their customers than the Code provisions, but they may not impose more onerous conditions.

In cases which involve consideration of the rules contained in the Code of Banking Practice, the role of the Banking Ombudsman is usually little different from the role in applying banking law in general. There may, however, be problems of interpretation, and there may be unusual facts underlying a complaint so that the rules are difficult to apply. In such cases the Banking Ombudsman also has the role of monitoring the Code and making recommendations for change. ${ }^{\text {is }}$

In a recent case, for example, the Banking Ombudsman had to consider the application of the rules relating to card fraud in circumstances where a customer had failed to advise his bank of a change of address and a card was sent to his former address where it was intercepted by his former wife. Although the selected PIN did not fall into one of the forbidden categories, her knowledge of his habits was such that she was able to guess it and used the card to withdraw substantial sums. Clause 5.1.3 of the Code states firmly that "you will not be liable for losses occurring before you receive your card". There is no provision for customers to bear the loss in whole or in part if they have contributed to it by their own negligence, as there is when cards are misused after they have come into the possession of the customer. In the next Code review, banks will be invited to consider whether there should be an amendment to cover cases where the failure to receive the card can be attributed

${ }^{14}$ The Code of Banking Practice does not apply to banks' relationships with their business customers. New Zealand has no equivalent to the Codes or statements of principle that apply to banks' relationships with at least their small business customers in Canada or the United Kingdom and which are in preparation in Australia.

${ }^{15}$ Clause 1.2 provides that the Code "...will be monitored by the Banking Ombudsman and reviewed in the Banking Ombudsman 's Annual Report, which is a public document." 


\section{THE DENNING LAW JOURNAL}

to the customer's negligence.

Other parts of the Code are less specific about the obligations that banks have undertaken and it is in this area that the Code is of more use as a guide in assessing what is fair in all the circumstances of the case than as a specific set of rules to apply. Clause 1.7.2, for example, requires banks to:

“. . make timely and adequate provision of information to help you understand how your bank accounts and banking services operate so that you can make an informed choice to best suit your needs."

A great many cases hinge on the timeliness and adequacy of information provided by banks to their customers, particularly as a perennial failing of bank staff is to make unwarranted assumptions about customers' understanding of bank processes. It is an interesting feature of the Banking Ombudsman's case load, for example, that although the volume of cheque transactions in New Zealand is declining as more and more transactions are made electronically, there is no matching decline in complaints to do with cheques. It seems likely that we are seeing a generation of bank customers who are not familiar with the use of cheques and who need more information than their predecessors about such matters as clearance times or crossings and endorsements.

An industry code of practice thus supplements in various ways the law relating to the complaints considered by the industry Ombudsman. The Code of Banking Practice displays the full range from repeating the substantive law to setting out rules that operate as a sort of de facto subordinate legislation to providing guidance in the form of statements of principle. Other codes are narrower in application. The Fair Insurance Code, for example, describes itself as a set of principles that guides the relationship between member companies and their customers and contains few rules. The collection of codes administered by the Advertising Standards Authority, on the other hand, are in general very detailed and in some cases have an appearance very similar to statutory regulations. ${ }^{16}$

\section{INFORMAL SUPPLEMENTS TO THE LAW - "FAIR IN ALL THE CIRCUMSTANCES"}

Codes of practice, as noted above, provide formal supplements to the law and also

${ }^{16}$ See, for example, the Code for Advertising Liquor, which has a definitions section and a statement of five basic principles followed by rules with sub-sections. 


\section{A FRAMEWORK FOR DISPUTE RESOLUTION}

some guidance for an Ombudsman faced with the need to decide what is fair in the circumstances of a particular case. Given the inquisitorial nature of the Ombudsman process, it is not surprising to find that Ombudsmen also seek out information about the standards that the members of their schemes should observe. In a number of the larger schemes, such as the Banking Ombudsman schemes in the United Kingdom and Australia, up-to-date expertise on the industry is provided by a resident adviser seconded from a scheme member.

Smaller schemes, such as the New Zealand Banking Ombudsman and Insurance and Savings Ombudsman schemes, cannot afford to support a full time adviser and rely on other means to ascertain the accepted standards of practice in areas where the relevant code of practice is silent or insufficiently detailed. Most commonly, the Banking Ombudsman consults with the banking industry by way of an industry survey on specific points of practice. Surveys are carried out with the assistance of the New Zealand Bankers Association and may be surveys of all scheme members or only of the main banks. ${ }^{17}$ The issues on which surveys have been conducted in recent years include:

- Responsibilities of paying banks when asked to accept a cheque where the name of the payee has been altered

- The appropriate information and advice to be given to merchants who make arrangements to accept payment by credit card for orders placed by telephone or mail.

- The form of a bank cheque on settlement of a sale of property

- Penalties on early repayment of a fixed interest rate loan

- Identification requirements for new customers

Consultation with the industry sometimes takes the form of consultation with nominated experts on bank systems. There is also the occasional consultation outside the industry as in a recent case where it was important to establish bank customers' rights to a review of legal costs incurred and paid by banks and later passed on to customers. Costs reviews are carried out by District Law Societies and a survey of the various societies proved useful and informative.

Practices among industry ombudsmen vary considerably according to the nature of the industry they cover and the statute, terms of reference or other basis for their appointment. Some make virtually all decisions on the papers while others routinely . conduct hearings or mediation meetings. Some base their decisions almost entirely

${ }^{17}$ The New Zealand scheme is very small by world standards. At its inception in 1992 there were seventeen member banks. Mergers and the withdrawal of some overseas banks have reduced that number to nine, only six of which have a substantial share of the retail market 
on the submissions made by the parties to the complaint while others are more inclined to investigate such submissions in detail and base their decisions on the results of that investigation. In doing so, all Ombudsmen apply the law, and all Ombudsmen ultimately rely on generally accepted standards of fairness and reasonableness, with greater or lesser assistance from formal or informal supplements to the law.

It should not be forgotten, however, that in many cases, at least in the New Zealand jurisdiction, complaints are resolved without the need to make a formal determination. In the $1997 / 8$ year formal recommendations were made in only $24 \%$ of the investigations completed. $40 \%$ of investigations terminated when an agreed settlement was reached. ${ }^{18}$

Appendix A to this paper consists of brief case histories of three very different types of complaint. In case 1, the Banking Ombudsman was called on to apply clear law and was acting no differently from a judge or referee. In case 2 , the inquisitorial process is seen in effect along with the use of the Code of Banking Practice. Case 3 is quite different. It illustrates a co-operative approach to complaint resolution that is a long way from litigation, and to my mind demonstrates much that is good about the Ombudsman process as an alternative to litigation.

\section{WORKING IN PARALLEL WITH THE LAW}

The earlier part of this paper discussed the means by which Ombudsmen use, supplement and act as an alternative to legal process. The cases -that come to Ombudsmen, however, may have implications beyond the subject matter of the complaint, and it is not unusual to find that while the Ombudsman is investigating or contemplating the investigation of a complaint, there are legal proceedings that impinge on the investigation. In the banking context, these are usually debt recovery proceedings and in a number of cases the complaint can only be regarded as an attempt to delay the inevitable bankruptcy or realisation of the loan security. Other cases, of course, raise a genuine question as to whether the bank should be embarking on recovery action.

Where there are current or completed legal proceedings directly on the subject of the complaint, the position is clear. Most industry Ombudsmen will be precluded from considering such a complaint. Paragraph 22(f) of the Banking Ombudsman's

${ }^{18}$ Of the remaining cases, $29 \%$ were withdrawn or abandoned by the complainant before the stage at which a formal recommendation would have been made, and in $7 \%$ a jurisdictional impediment appeared during the course of the investigation. 


\section{A FRAMEWORK FOR DISPUTE RESOLUTION}

Terms of Reference provides:

"The Banking Ombudsman shall only consider (or continue to consider) a complaint made to him or her if he or she is satisfied that:

(f) neither the complaint made to him or her nor any other complaint by the same complainant (or any one or more of them) in respect of the same subject matter is, has been or becomes to the knowledge of the Banking Ombudsman the subject of any proceedings in or before any court, tribunal or arbitrator, or any other independent or statutory complaints or conciliation body, or of any investigation by a Statutory Ombudsman;"

From time to time banks, or more frequently their legal advisers, suggest either that the complainant ought to pursue the complaint by taking legal action against the bank or that the bank should issue proceedings against the complainant and leave the subject matter of the complaint to be raised by way of defence. A bank may effectively prevent the Banking Ombudsman from commencing or continuing an investigation by taking legal action against the complainant. It is clearly contrary to the purposes and spirit of the Banking Ombudsman scheme for a bank to do this if it is aware of the Banking Ombudsman's involvement with a complaint, and on the rare occasions when such action has been threatened, it has usually been by a newcomer to the bank's legal team.who is not familiar with the nature of the Banking Ombudsman scheme. Discussions at a more senior level have to date invariably resolved the difficulty.

Paragraph $18(\mathrm{~d})$ of the Banking Ombudsman's Terms of Reference provides that the Banking Ombudsman may decline to consider a complaint:

"if at any time it appears to the Banking Ombudsman that it is more appropriate that the complaint be dealt with by a court, under another independent or statutory complaints or conciliation procedure or under an arbitration procedure;"

Accordingly if a bank considers a matter would he more appropriately determined by a court, it has two options:

(i) It may ask the Banking Ombudsman to consider declining jurisdiction under Paragraph 18(d): or

(ii) It may invoke the "test case" process whereby, with the Banking Ombudsman's 
approval, complaints involving important or new points of law or with important consequences for the bank's business may be litigated on the bank's undertaking to pay the complainant's costs. ${ }^{19}$

The test case process has not been used in New Zealand, although in two cases the Banking Ombudsman has indicated that she would be likely to approve its use. Both cases were ones where a finding in favour of the complainant would have obliged the bank to consider the impact on its relationship with numbers of customers with potentially serious consequences for its business.

The discretion given by Paragraph 18(d) is exercised sparingly. It is most often used in cases where part of the complaint falls within the Terms of Reference but there are major issues that are excluded from the Banking Ombudsman's consideration and it is desirable that all issues be considered together. It has also been used in cases where the complainant has access to a specialist complaints-handling process such as the complaints division of the Privacy Commissioner's Office or the Human Rights Commission and ultimately the Complaints Review Tribunal. ${ }^{20}$ In general, however, complainants ought not to be denied access to the forum of their choice, and the Banking Ombudsman will consider a complaint unless there are manifest reasons why such consideration would be inappropriate.

Rather different issues arise when a complainant asks the Banking Ombudsman to investigate a complaint and the bank has already commenced proceedings or other recovery action or has taken some preliminary steps in that direction. If proceedings have been commenced and are on the same subject matter as the complaint, then the decision is simple: the complaint falls outside the Terms of Reference. Matters are more complicated when the proceedings are not directly on the subject matter of the complaint or where the bank has indicated that it intends to take proceedings and has completed some preliminary processes but has not yet actually issued proceedings or where it has, for example, set in motion a mortgagee sale process.

It is at this point that the Ombudsman process can become closely entwined with the legal process and it sometimes becomes difficult to ensure that the investigation does not prejudge the issues or otherwise trespass on the province of the courts.

If at all practicable, the bank is asked to refrain from any action that will

${ }^{19}$ Paragraphs 23 and 24 of the Banking ombudsman's Terms of Reference.

20 The Complaints Review Tribunal reviews complaints that were originally made to organisations such as the Privacy Commissioner or the Human Rights Commission. 
irreversibly affect the outcome of an investigation. The decision to make such a request is not taken lightly as there is a need to recognise that both the bank and its customer may be disadvantaged by any delay. A postponement of action may mean extra costs for either party. The bank may have incurred legal and other costs that will eventually be passed on to the customer, penalty interest may be accruing, the security may be deteriorating.

It is sometimes possible to separate the subject matter of the complaint from the subject matter of the proposed action. A bank is not generally asked to suspend action when, for example, the complaint is solely about the handling of the debt recovery process or is a complaint of breach of privacy and there is no obvious monetary loss to the complainant. Nor is a bank asked to suspend action if it is clear that, whatever the outcome of the investigation, the action is going to be necessary to recover a debt. If there is a dispute about the amount the bank is entitled to recover, but even on the most favourable calculation the complainant's obligations can only be met by the sale of the security, then there is little point in postponement.

The most difficult cases are those where a determination of the complaint in favour of the complainant will mean that no legal action is necessary. The Banking Ombudsman has no power to require a bank to postpone action while a complaint is investigated and there have been occasions when a bank has been extremely reluctant to comply with a request to do so. To a certain extent the problem has been overcome by the Banking Ombudsman's publication of a set of guidelines which will be followed when deciding whether a bank should be requested to suspend legal action, cancel auction arrangements or otherwise refrain from irreversibly affecting the complainant's position. ${ }^{21}$ The guidelines make it clear that such a request will not be made unless it is necessary to protect the status quo and that the Banking Ombudsman will always be prepared to discuss with banks any steps they may wish to take to protect their position without prejudicing that of the complainant.

It is in the acceptance by banks of such measures that one of the greatest strengths of the Banking Ombudsman scheme lies, and indeed it reflects one of the strengths of many industry ombudsman schemes. It is inherent in an effective scheme that the Ombudsman is totally impartial and independent of scheme members in determining complaints. The commitment of members to the scheme that they have established, promoted and funded, however, means that it is entirely possible for the Ombudsman to work with scheme members to strengthen and improve the process that is offered as an alternative to litigation.

At its best, an Ombudsman scheme is sufficiently strong and flexible to work

${ }^{21}$ In her annual report for the $1996 / 7$ year. 
within the law and alongside the law but always with a view to working with the organisations over which its jurisdiction lies to resolve the problems of their complainants. only when resolution by cooperation proves impossible should an Ombudsman process take on a closer resemblance to the legal process and provide an authoritative determination of a complaint.

\section{APPENDIX A - SOME CASE HISTORIES}

\section{CASE 1}

Ms. B had separated from her husband, Mr R. The marriage had been a violent one and Ms B had obtained a protection order against Mr $\mathrm{R}$. She called into her bank to inform it of the ending of her marriage, to close her joint account with $\mathrm{Mr}$ $\mathrm{R}$ and to change the name on her accounts from her married to her maiden name. Ms $\mathrm{B}$ made it clear to the bank that she wanted nothing further to do with $\mathrm{Mr} \mathrm{R}$. She then moved to a different part of the country and advised the bank of her new address.

Mr R called into the bank and was able to arrange for Ms B's bank statements to be sent to a Post Office box that he had opened. Ms B was very shocked and distressed to learn that, despite her efforts, Mr R was receiving copies of her bank statements and was aware of the place in which she was now living. In fact, by looking at the pattern of her EFT and ATM transactions, he could probably have traced her quite easily. Ms B was so concerned for her safety that she felt she had no option but to relocate immediately and moved to another town. In moving Ms B incurred the cost of removal and lost the bond she had paid for her flat as she was unable to give the notice required by the term of her lease.

A complaint was lodged with the Banking Ombudsman, who was able to establish that Ms B did not authorise the change of address to the Post Office box. She found a clear breach of the Privacy Act 1993, and recommended that the bank pay Ms B's removal costs together with a substantial sum by way of compensation for inconvenience.

\section{CASE 2}

When Ms $\mathrm{M}$ was unexpectedly made redundant from her job, a friend suggested that she ask her bank for a mortgage holiday in order to give her some breathing space until she found new employment. The next day Ms M telephoned her bank to explain her circumstances. The bank officer was very understanding 


\section{A FRAMEWORK FOR DISPUTE RESOLUTION}

and told her over the telephone that she could have a three month loan repayment holiday effective from her next mortgage payment date. The bank later faxed through to Ms $M$ the relevant application form which a grateful Ms $M$ signed and faxed back to the bank.

Upon resumption of her mortgage payments three months later, Ms $\mathrm{M}$ was dismayed to discover that a lump sum of approximately $\$ 4,500$, (which was equivalent to the three individual monthly instalments of interest which had not been debited during the period of the holiday, the amount of the next monthly payment due and a sum of approximately $\$ 40$ being interest accrued on the payments which were not made over the holiday period), had been debited to her loan account. The result of this was to increase her principal sum, which would mean that $\mathrm{Ms} M$ would pay an estimated $\$ 5,000$ in additional interest over the remaining term of the loan, and to extend the term of her loan by two years.

Ms $\mathrm{M}$ immediately complained to the bank that she had been misled as to the effect of the holiday. Her understanding had been that she was trading three months' payments now for three months' payments at the end of the loan, that is, the term of her loan would be extended by three months as a result of the holiday. She had taken a reference to accrual of interest in the application form to mean that interest would accrue on the three payments she was deferring (a few hundred dollars) and not on the principal sum.

The bank denied having misled Ms $\mathrm{M}$. It noted that Ms $\mathrm{M}$ had acknowledged on the application form that interest would continue to accrue. As with all borrowing, interest was charged on the entire amount owing to the bank and there was nothing on the form or in any of the bank's representations which could have led Ms M to believe that the bank would change the way in which it charged interest. The Bank referred Ms $\mathrm{M}$ to the Banking Ombudsman.

Although banks had for some time been prepared to offer loan repayment holidays, it was only recently that they had been promoted as a new and attractive part of a housing loan package. The Banking Ombudsman accordingly obtained and considered the promotional literature put out by banks and checked the calculations used to determine changes in loan terms and repayment instalments as a consequence of a repayment holiday. She found that the "holiday" was effectively a top-up or further loan consisting of the amount of the instalments that would have been paid if the holiday had not taken place.

It was inappropriate for a product of this type to be sold or arranged entirely over the telephone. The customer should be asked to attend at the branch to sign the application form and should be given a proper and detailed explanation as to the effect of the loan repayment holiday, including: 
- The amount of the lump sum that would be debited to his or her account at the end of the holiday period.

- The new end date of the loan if he or she did not wish to increase his or her loan repayments; and

- The approximate amount in additional interest that the customer would pay over the remaining life of the loan.

Only by providing such information would the customer be equipped to make an "informed choice" as to whether or not the loan repayment holiday was best suited to his or her needs (Clause 1.7.2 of the Code of Banking Practice referred).

It was clear that Ms. M had not been provided with any such information. Although she had read the application form, the phrase "interest will continue to accrue" was not sufficient by itself to fully inform her of the effect of the holiday. The Banking Ombudsman did not think the bank could automatically assume that all of its $\mathrm{c}$ ustomers were sufficiently knowledgeable about loan products or lending principles to understand that the expression "interest will continue to accrue" in this context meant that interest would continue to accrue on the principal of the loan as opposed to Ms M's understanding that interest would continue to accrue only on the unpaid loan payments.

The bank had therefore failed in its obligation to inform Ms $M$ of the consequences of taking out the loan repayment holiday. The Banking Ombudsman recommended a reorganisation of the loan so that $\mathrm{Ms} M$ was put in the position that she had expected to be in at the conclusion of the holiday.

\section{CASE 3}

Mr D had two accounts with his bank. There was a cheque account which, at the time he approached the Banking Ombudsman, had an unauthorised overdraft of approximately $\$ 500$. He also had a savings account.

The conduct of the accounts had been unsatisfactory to the bank for some time and during March 1998 the bank wrote to Mr D saying that it intended to close his accounts. It wrote again in early April to a different address and finally hand delivered a letter on the Thursday before Easter. Because of his frequent changes of address, the last letter was the only one that reached $\mathrm{Mr} \mathrm{D}$.

Immediately after Easter, on the Tuesday, Mr D contacted the bank but it was not prepared to make any concessions and the following day the accounts were closed. This meant Mr D was unable to access his social welfare benefit payment which had been direct credited to his account. The bank advised him that it would be taken in part payment of the overdraft. Mr D submitted that this left 


\section{A FRAMEWORK FOR DISPUTE RESOLUTION}

him without any funds for living expenses and, in particular, necessary medication.

An investigator from the Banking Ombudsman's office contacted the bank as a matter of urgency and facilitated an agreement between $\mathrm{Mr} \mathrm{D}$ and the bank

whereby Mr D was permitted access to funds for living expenses, and agreed to a repayment programme that would see the overdraft extinguished reasonably quickly, at which point his accounts with the bank would be closed and he would arrange to open accounts with another bank. 